\title{
Prekarya Tartışmaları
}

Kavram, Tanım ve Durum*

\author{
Merve Akkuş Güvendi
}

\section{Giriş}

Fransa'da Kasım 2018'den bu yana "Sarı yelekliler" adı ile bilinen protesto gösterileri ne sadece Fransa ve Avrupa ile sinırlı tutulabilir ne de ilk ya da son olma özelliği taşımaktadır. Küresel düzeyde yaşanan gelir eşitsizlikleri, toplumların ekonomik ve kültürel olarak kutuplaşmasına neden olmaktadır. 2000'lerin başından bu yana kendini gösteren huzursuzluk ve sorunlar, 2008'de Büyük Durgunluk sonrasında daha da artmış ve 2011'deki devrim ayaklanmaları ile yeni biçimler almıştır. Sosyal adalet ve güvencesiz çalışma paydasında birleşen taleplerin temelinde aslında 1970’lerden bu yana küresel bir dönüşüm geçiren emek-sermaye ilişkileri bulunmaktadır. Fordist-Keynesyen sistemin üretim ve örgütlenmede yerini daha esnek bir yapılanmaya bırakması ile "yeni kapitalizm" in siyasi ve toplumsal tezahürleri ortaya çıkmaktadır. Neoliberal devlet politikaları ile piyasa merkezli yaklaşım ve düzenlemeler, üretimin esnekleşmesi ve güvencesiz hâle gelmesi, emeğin sermaye karşısındaki gücünü gittikçe zayıflatmıştır.

Güvencesiz çalışma ve esnek istihdam ile üretim yapısında "prekarya" olarak karşılık bulan bu durum daha sonra Guy Standing'in 2011 yllında dünyada çok ses getiren The Precariat: The New Dangerous Class (Prekarya: Yeni Tehlikeli Sinif) çalışmasıyla birlikte yeni istihdam koşullarının ortaya çıkardığı bir aktör veya sınıf olarak tartışılmıştır. Kavramın çerçevesinin oluşturulmamış olması, tanımlama-

* Bu yazı TÜBİTAK tarafindan desteklenen 217K184 nolu “Türkiye’de Sosyal Hareketliliğin Yapısı ve Biçimleri” başlıklı araştırma kapsaminda üretilmiştir.

@ Dr. Öğrencisi, İstanbul Medeniyet Üniversitesi, merveaks@gmail.com

(iD https://orcid.org/0000-0003-2754-3606 
daki muğlaklıklar ve temel aldığı literatürdeki farklılıklar, Standing'in tanımladığ1 prekaryaya yoğun eleştirilerin gelmesine neden olmuştur. Bu kapsamda Standing'e, prekaryanın yeni bir sınıf olarak tanımlanması, Avrupa merkezci bakış açısı, coğrafi yanlılık ve güvencesizliği hâlihazırda yapısal bir sorun olarak tartışması yönünde eleştiriler gelmiştir. Fakat tüm bu eleştirilere ek olarak ihmal edilen dördüncü bir husus bulunmaktadır. Prekaryayı Marksist terminoloji ile eşitsizlik ve sınıf bağlamında değerlendiren Standing, eski sınıfsal niteliklerle yeni toplumsal grupları değerlendirmekte, toplumsal sınıfların dinamikliğini ve yeni koşullarla farklı özelliklerinin ortaya çıktığını göz ardı etmektedir. Bu yazıda öncelikle prekarya tartışmalarının zeminine ve Standing'in prekarya tanımlamasına yer verilecektir. Standing'in tezleri etrafındaki tartışmalar detaylı olarak ele alınacak ve eleştiriler değerlendirilecektir. Nihayetinde ise bu kavram ve analize yönelik yeni eleştiriler ile birlikte kavramın daha kullanışı bir hâle getirilmesi sağlanmaya çalışılacaktır.

\section{Prekaryayı Tartışmak}

Güvencesizlikle ilgili tartışmalar ilk olarak 1980'lerde, Margaret Thatcher ve Ronald Reagan'in İngiltere ve Amerika'da göreve gelmesinden sonra yaygınlaştı. Bunun temelinde neoliberal ekonominin tezahürleri bulunmaktaydı. Kapitalizmin tarihinde bir dönemeç olan bu zaman diliminde neoliberalizm, Keynesçiliğe alternatif uygulanabilir bir ekonomik program olarak ortaya çıtı. Kapitalizmin eski temel alanları küçülerek bilgi, dijitalleşme ve gelişen teknolojik kapitalizm ile kapsamlı bir dönüşüm yaşandı. Başka bir deyişle neoliberalizm, bilgi devrimini ve ağ toplumunun doğuşunu destekleyerek yeni ekonominin kurumsal çerçevesini oluşturdu. $\mathrm{Bu}$ çerçevede ise esnekliği ve niteliği yüksek emeğin değeri ve yapısı değişti.

Bu dönüşümün ardından güvencesiz çalışmayı analiz eden yaklaşımlar, sosyolojinin temel tartışmaları arasında yerini kısa sürede aldı. Kalleberg ve Vallas (2018) bu yaklaşımların ayrı ayrı ortaya çıktığını ancak büyük ölçüde birbirini tamamlar nitelikte genişlediğini belirtmektedir. Bunlardan ilki, modernliğin merkezine güvencesizliği yerleştiren yaklaşımlardır. Giddens'in (1991) "ontolojik güvenlik", Beck'in (1992) "risk toplumu", Bauman'ın (2000) "akışkan modernite" kavramsallaştırmaları, güvencesizliğin moderniteye içkin olduğu gerçeğini vurgulamaktadır. Diğeri ise son otuz yılda güvencesiz çalışmanın artışını açıklamaya çalışan ampirik çalışmalardır. Fordist istihdam süreci sonrasında süreci aşındıran yapısal güçleri tanımlamaya çalışan bu araştırmalar birbiriyle ilişkili dört belirgin faktör üzerinden ilerlemiştir: Sendikalaşmanın azalması, finansallaşma, küreselleşme ve tek- 
nolojik devrim (Kalleberg ve Vallas, 2018, ss. 1-5). İki ana akımda Fordist rejimin istikrarlı, güvenli bir istihdam sağlama vaadinin çözülme sürecini vurgulamaktadır. Güvencesiz çalışma üzerinden ilerleyen tartışmalar, esnek istihdam ile birlikte üretim yapısında "prekarya” olarak karşılık bulmuştur.

İlk defa 1980'li yıllarda Fransız sosyologlar tarafından geçici ve mevsimlik işçileri tanımlamak için kullanılan prekarya kavramı daha sonraları ekonomik, sosyal ve felsefi bir tartışma zemini hâline gelmiştir. Standing (2014, s. 13) prekarya kavramının öncüleri arasında Pierre Bourdieu, Michel Foucault, Jürgen Habermas, Michael Hardt ve Tony Negri ve arka planda Hannah Arendt'i saymaktadir. Kavramı çalışma yaşamı ile ilk kullanan Bourdieu'dür. Bourdieu, 1963'te Cezayir'de çalışma koşulları üzerine yaptığı araştırmada düzenli ve düzensiz işçileri ayırt etmek maksadıyla precarite kavramını kullanmıştır. 1998 yılında "güvencesizliğin her yerde” olduğu tespiti sonrasında çalışma ve yaşam koşullarındaki belirsizliği ve güvencesizliği ifade eden bir kavram olarak Bourdieu tarafından kullanıldı. İlerleyen zamanda kavram, Butler (2006) tarafından da daha felsefi bir bağlamda tartışıldı ve 2011 'de dünyanın birçok ülkesinde patlak veren sosyal hareketlerle kamusal tartışmalarda da yer almaya başladı.

Prekarya, prekaryalaşma, eğretileşme, güvencesizlik, güvencesizleştirme gibi daha birçok benzer kavramla birlikte kullanılmaktadır. Literatürde kavramla ilgili iki farklı ama çoğu zaman birbiri ile iç içe geçen iki yönelim bulunmaktadır. Bunlardan biri Bourdieu, Foucault, Butler, Hardt ve Negri ve daha sonra Lorey ile devam eden güvencesizliğin neoliberalizm ile topluma içkin hâle gelen ontolojik bir kavram olarak ele alınmasıdır. Diğeri ise Guy Standing'in dünyada çok ses getiren çalışmasıyla birlikte prekaryanın esneklik ve güvencesizlik ile şekillenen yeni istihdam koşullarının ortaya çıkardığı bir aktör veya sınıf olarak ele alınmasıdır. Bu değerlendirme/yorumlama aslında prekaryayının aktör, sınıf, eylemlilik ile daha politik bir zeminde tartışılmasını sağlamıştır. Nitekim kavram 2000'li yılların başında Avrupa'da güvencesiz çalışmaya karşı yeni toplumsal hareketin yükselişinin anlamlandırılmasında önemli bir rol oynamıştır.

1970 sonrası üretimdeki yapısal değişikliklerin emeğe olan etkisinin sorunsallaştırılması "maddi olmayan emek" tartışmalarını başlatımıştır. İtalyan Marksist sosyolog Maurizio Lazzarato tarafindan 1996 y1lında "maddi olmayan emek" (immaterial labor) Fordizm sonrası olarak tanımlanan kapitalist üretim tarzındaki değişikliklerin bir sonucu olarak teorileşmiştir. Kavram daha sonra Hardt ve Negri'nin (2003) Imparatorluk adlı eserinde maddi olmayan emeğin öteki yüzü, insani ve etkileşime açık olan tarafı olarak duygulanımsal emek (affective labour) ile 
belirtilmiştir. Lazzarato (1996), 1970’lerin başından itibaren metaların bilişsel ve kültürel içeriğe sahip olduğunu belirtmektedir. Maddi olmayan emeği ise emeğin değişen bu iki boyutunu işaret ederek açılamaktadır. Metaların bilişsel içeriklerinin üretimi, sanayi ve hizmet sektöründe çalışanların üretim süreçlerinde siber teknik ve bilgisayar kontrolü gerektiren niteliklere sahip olması demektir. Diğer taraftan metaların kültürel içeriğinin üretimi ise kültürel ve sanatsal standartları, modayı, zevkleri, tüketici normlarını düşünerek işin yapılması anlamına gelmektedir. Daha önceleri burjuvaya ve çocuklarının ayrıcalıklı dünyasına ait olan bu durum sonraları "kitlesel entelektüelliğin" (mass intellectuality) parçası hâline gelmiştir. Öznenin ve öznelliğin bu yeni biçimi, toplumsal sınıflar arasında yeni bir çatışma unsuru hâline gelmiştir. Öte yandan maddi olmayan emeğin, üretimin sadece kapitalist talep ettiğinde işleyen bir mekanizma hâline gelmesine sebebiyet vererek esneklik, sömürü, hiyerarşi ve dahası güvencesizliği ortaya çıkarmaktadır.

Konunun felsefi olarak tartışması Butler tarafından devam ettirilmiştir. Butler (2006) güvencesizliği, küresel ölçekte bazı toplulukların toplumsal, iktisadi ve siyasal destekten mahrum bırakılarak kırılganlaştırıldıkları ve her türlü riske açık hâle gelmeleri durumu olarak tanımlamıştır. Butler, hayatın, bedenin güvencesiz olmasının sadece bir tehdit ya da tehlike olmadığını aynı zamanda bir ihtiyaç olduğunu belirtmektedir. Ekonomik ve sosyal olana içkin olan bu güvencesizlik oldukça politik bir alandir.

Lorey (2011) ise Butler'dan aldığı referansla tartışmayı ontolojik bir zeminde devam ettirmiştir. Lorey, Hardt ve Negri'nin “ortak” (common) kavramı ile birlikte düşünerek prekarizasyonu varoluşsal bir güvencesizlik olarak ifade etmiştir. Lorey (2011, 2015), çağdaş neoliberal toplumların artık sosyal güvencesizliği içsel bir mekanizma olarak yönettiğini ve bunun hızlı bir normalleşme sürecinde olduğunu belirtmektedir. Bu durumun yeni yapısal konumunu göstermek için güvencesizliğin üç boyutunu birbirinden ayırmaktadır. Bunlar sosyoontolojik bir durum olarak belirsizlik (precariousness), kimliksel bir konumlandırma olarak güvencesizlik (precarity), yönetilebilir hâle getirmeye dayalı bir yönetim anlayışı olarak güvencesizleştirme (precarization). Öncelikle sosyoontolojik boyutu belirten güvencesizliği (precariousness) açıklamaktadır. Lorey, Butler'dan aldığı referansla güvencesizliğin hayatın içerisinde, tarihsel ve coğrafi olarak farklı görünümleri bulunduğunu belirtmektedir. İnsanın bir toplum içerisindeki kabulü ve yaşamı, mücadelesi ile bir bütündür. Bu nedenle sosyal çevre ile paylaşım, koruma ve güvenliği beraberinde getirir. İkinci olarak güvencesizlik, yapısal eşitsizlikler, cinsiyet, ırk, etnik köken, sınıf çizgileri boyunca tahakküm ilişkilerinden kaynaklanan belirsizliklerdir. Güvencesizlik, belirsizliği, eşitsizlik koşulları ve hiyerarşik olarak bir yere konumlan- 
dırmakta ve onu ötekileştirmektedir. Güvencesizliğin bu boyutu, bir gruba mensup kişilerin bireye atfedildiği veya reddedildiği doğallaştırılmış hâkimiyet ilişkilerini kapsar. Son olarak ise kendi yaklaşımını da temellendirdiği yönetimsel güvencesizleştirmeyi (governmental precarization) açıklamaktadır. Sürekli güvencesizlikle hâkim yönetim, toplumdaki sosyal bağları, yapıları, ilişkileri ve dinamikleri daimî bir güvensizlik korkusuyla birleştirir. Bu durum ise geçerli bir güvensizlik hissinin sürekli olarak üretilmesine neden olur. Lorey bir yönetim sistemi olarak güvencesizleştirmenin sadece ücretli emek yoluyla istikrarsızlaştırılması değil aynı zamanda bedenin ve yaşamın da istikrarsızlaştırılması anlamına geldiğini belirtmektedir. Birbirinden bağımsız olarak ortaya çıkmayan bu üç yön, tarihsel olarak incelendiğinde birbirinin yerine de konumlanmıştır.

Lorey (2011, s. 8), prekarizasyonu/prekaryalaşmayı neoliberal bir yönetim arac1 olarak görmektedir. Politik olarak güvencesizliğin kendi içinde üretken bir yapısı bulunmaktadır. Bir yönetişim aracı ve ekonomik sömürü durumu olarak hesaplanamaz ve potansiyel olarak güçlendirici bir sübvansiyondur. Bu kabul, ekonomik sömürü şartları ve öznelleştirme biçimleri ile iktidar ve güçlendirme arasında oluşan belirsizlikleri, karmaşık etkileşimlerin sorunsallaştırılmasını mümkün kılar. Böylece sadece baskıcı, sınırlandırıcı bir unsur olarak değil kendi kendini yönetme teknikleriyle ortaya çıktığında da belirsiz üretken durumları bulunmaktadır. Güvencesizliği Foucault'un yönetimsellik (governmentality) teorisinin çerçevesinin içine konumlandırarak güvencesizliğin içselleştirilmesini tartışmaktadır. Neoliberal yönetimsellik, güvencesizliği, sistematik sınıflandırmalar ve hiyerarşiler yoluyla ekonomik, sosyal ve yasal eşitsizlik ilişkileri üzerinden "beden" ve "kültür" ile yeniden üretmektedir. "Öz prekerleşme"yi (self-precarization) beraberinde getiren bu süreç, güvencesizleşmeye zorlananlar olarak değil "güvencesiz yaşam koşullarını özgürce seçenler" olarak ilerlemektedir (Lorey, 2011, ss. 6-7). Yaşamın artık her alanına nüfuz etmiş ve yöneten-yönetilen ilişkisi başta olmak üzere toplumun geneline yayılmış olan bu durum Lorey'e (2011) göre geçici, marjinal ya da anormal bir durum değildir. Gittikçe normalleşmekte, bir tahakküm biçimi olarak kendini üretmekte ve korku ile birlikte toplumsal ilişkilerin ortasında kendine yer edinmektedir.

\section{Standing'in Yeni Tehlikeli Sınıfı: Prekarya}

Bu düşünsel ve analitik arka plan dâhilinde günümüzde prekarya tartışmalarının odağında Guy Standing'in 2011'de yayımlanan ve 2014'te Prekarya: Yeni Tehlikeli Sınıf başlığıyla Türkçeye çevrilen kitabı bulunmaktadır. Özellikle prekaryanın bir aktör ve sınıf oluşu bağlamındaki tartışmalar burada önemli bir konum tutmak- 
tadır. Özellikle Avrupa ülkelerinde 1990’larda başlayan ve 2000 sonrası artarak devam eden gösteriler, esnek istihdam ve güvencesizlik etrafındaki tartışmaların daha da yoğunlaşmasına neden olmuştur. Böylece prekaryanın bir politik aktör olduğu tezi, akademik çalışmalarda kendine geniş bir yer bulmuştur.

Standing (2014) tarafından "küreselleşmenin çocuğu" ve "oluşmakta olan bir sınıf" olarak tanımlanan prekarya, esnek emek istihdamının bir neticesi olarak görülmektedir. Prekarya nitelik açısından çoğu zaman kısa süreli veya geçici işle yaşar. Refah devleti döneminde edinilen maaşların iş gücü güvenliği biçimlerinin hiçbirine sahip değildir ve nispeten düşük ve güvensiz kazanç sağlayarak hayatına devam eder.

Esnek istihdamın hızla yayıldığı ve eşitsizliklerin de artmasıyla birlikte sanayi toplumunun temelindeki sınıf yapısının yeri farklılaşmaktadır. Sınıf ortadan kaybolmamakta, farklılaşarak parçalı bir sınıf görüntüsü ortaya çıkmaktadır. Bu parçalı yapı içerisinde kendine özgü bir yeri bulunan prekaryanın sınıfsal pozisyonu “işçi sınıfı" ya da "proletarya"nın bir parçası değildir. Proletarya uzun dönemli, güvenceli, sendikalaşmanın ve sözleşmenin olduğu, kademelendirilme sistemi içinde bulunmaktadır. Prekaryada ise çalışanların esnek ve geçici konumları, onu nesnel bir kategoride değerlendirmeyi mümkün kılmamaktadır. Öte yandan ise prekarya "orta sınıf" da değildir, bu sınıftan olan insanların sahip olabileceği sabit ya da öngörülebilir bir maaş ya da statüleri bulunmamaktadır (Standing, 2014, s. 20).

Standing'e (2018) göre günümüzde prekarya üç yönüyle tanımlanabilir: Kendine özgü üretim ilişkileri (emek ve çalışma kalıpları), kendine özgü dağıtım ilişkileri (sosyal gelir kaynakları) ve devlete özgü ilişkiler (vatandaşlık haklarının kaybı). Böylece istenilen reformların ve sosyal politikaların kendine özgü bir "bilinci” ortaya çıkabilecektir. Prekarya ise içsel olarak farklı göreceli yoksunluk ve bilinç duyularıyla bölünmesinden dolayı Marksist ifadeyle tam olarak kendi için (class for itself) sınıf olarak tanımlanamayacağından oluşmakta olan bir sınıf (class in the making) olduğu iddia edilebilir (Standing, 2018, ss. 4-5). ${ }^{1}$

Standing'in (2012, s. 589; 2014, ss. 12-13) iki farklı çalışmasında kapitalist toplumların yedi sınıftan oluştuğu belirtilir. Bunlar sırasıyla:

1 Marx'ın "kendinde sınıf" ve "kendisi için sınıf” kavramlarıyla yapmaya çalıştığı ayrım, toplumsal bir özne olan işçi sınıfının, siyasal bir özne hâline gelmesi sürecini dile getirmektedir. Proletarya kendi konumunu ve burjuva karşısındaki konumunu kavradığında kendinde sınıftan kendisi için sınıfa dönüşebilecektir (Sunar, 2018, s. 28). 
(i) Elitler ya da pülütokratlar: Marksist anlamda gerçek yönetici sınıf olarak.

(ii) Ücretliler: Büyük şirketlerde istihdam edilen, devlet ve şirket tarafından sağlanan haklardan faydalanan geleneksel ücretli kesim.

(iii) Profesyoneller: Profesyonel ve teknisyenin birleşimi olarak pazarlayabilecekleri vasıflara sahip, sözleşmeye dayalı yüksek gelire sahip gruplar.

(iv) Proletarya: Kitle üretimi içerisinde, geliri ücrete dayanan, üretim mekanizmaları üzerinde hakkı bulunmayan eski merkezî çalışanlar.

(v) Prekarya

(vi) $\dot{\text { Issizler }}$

(vii) Lümpen prekarya ya da sınıf-altı (toplumun tehlikelerinden uzak müstakil olarak kötü uyumsuz grup).

İlk olarak kendine özgü üretim ilişkileri (emek ve çalışma kalıpları) vardır. Esnek çalışma koşulları, geçici iş sözleşmeleri, saatlerin belli olmadığı çalışma durumu prekaryayı mesleki bir kimlikten ve geleceği hakkında bir hikâye oluşturma imkânından uzak tutar. Belirsizlik durumu, ihtiyaçlarını ve yeteneklerini sürekli revize etme ihtiyacı doğurur bu ise sürekli bir stres hâlidir. İkinci olarak kendine özgü dağıtım ilişkilerinden (sosyal gelir kaynakları) yoksundur. Prekaryanın gelir güvensizliğinin anahtarı, belirsizliktir. Belirsizlik, işsizlik, doğum ve hastalık gibi acil durum risklerinden refah devletlerinin temel odağı olan olanaklardan farklıdır. Bunlar için böyle olayların olasılığını hesaplayabilir ve bir sigorta planı geliştirebilir. Fakat belirsizlik durumunda sosyal güvenlikten ve sigortadan bahsedilemez. Dahası yaşamın pahalılığı ve hesapta olmayan durumlar için kredi almak, faiz ödemesi yapmak, prekaryayı daha da dibe çekmektedir. Üçüncü olarak devletle ilişkilerde prekarya var olan haklarını da kaybetmektedir. Korunmaya ihtiyaç duyana kadar da bu durumunu fark etmemektedir. Hem siyasi hem ekonomik haklarını ise yapmak için nitelikli oldukları meslekleri yapmadıklarından dolayı kaybetmektedirler (Standing, 2018, ss. 4-6).

Peki hangi gruplar prekaryadır? Standing (2015, ss. 7-8) prekaryanın üç farklı gruptan oluştuğunu belirtmektedir. (i) Bunlardan ilki, eski işçi sınıfının ve ailelerinin çocuklarıdır. Standing bu kesimi atavist olarak adlandırmaktadır. Çoğunlukla eğitimsiz olan bu gruptakiler, yoksunluk ve hayal kırıklığı duygularını gerçek veya hayal edilmiş bir geçmişle ilişkilendirme eğilimindedirler. Böylece aşırı sağın gerici popülist seslerini dinlemekte ve sorunlarının kaynağı olarak ikinci veya üçüncü 
grupta olanları görmektedirler. (ii) İkinci grup prekarya ise göçmenler ve azınlıklardan oluşmaktadır. Bu grup ise yoğun yoksunluk hissinden dolayı şimdiye ve bir yuvaya sahip değildir. (iii) Üçüncü gruptakiler ise düzensiz işlerde çalışan ve kendilerine bir yaşam anlatısı kuramayan, statü konusunda hayal kırıklığı yaşayan eğitimlilerdir. Bu gruplar üzerinden değerlendirildiğinde ise modern prekaryanın öncelikli olarak bir sosyal hafızası yoktur. Dahası bunu oluşturma ya da bir gruba ait olma durumları da bulunmamaktadır. İkinci olarak ise prekarya, gelecekte birlikte hareket etme ya da birlikte bir mücadeleyi sürdürebilme yetisine de sahip değildir. Son olarak ise prekarya, vatandaş değil sadece bir yerde mukim olan kişidir. Sınırlı ekonomik haklar verilen, önemli kısmı göçmen olmayan bu grup, kendi doğduğu ülkede vatandaştan daha az hakka sahiptir (Standing, 2012, s. 590).

Standing (2014, s. 26) prekaryanın İkinci Dünya Savaşı sonrası süreçte sosyal demokratlar, işçi partileri ve sendikalar aracılığıyla inşa edilen "sanayi vatandaşlığı" kavramının kapsamında yedi tip güvenceden yoksun olduğunu belirtmektedir:

(i) Emek piyasası güvenliği: Yeterli gelir kazanma olanakları.

(ii) İstihdam güvenliği: Keyfî işten çıkarmalara karşı koruma, işe alma ve işten çıkarma ile ilgili düzenlemeler vb.

(iii) İ̧̧ güvenliği: İstihdamdaki bir alanı korumak için yetenek ve fırsata sahip olma.

(iv) Çalışma güvenliği: İş kazalarına ve hastalıklara karşı koruma.

(v) Vasıfların yeniden üretiminin güvenliği: Çıraklık yoluyla beceri kazanma fırsatı.

(vi) Gelir güvenliği: Yeterli sabit gelirin sağlanması.

(vii) Temsil güvenliği: İş gücü piyasasında serbest sendikalar vasıtasıyla ortak grev hakkına sahip olma).

$\mathrm{Bu}$ unsurların yoksunluğu ise prekaryalaşmanın toplumda artan öfke, kaygı, yabancılaşma ve dışlanmışlık ile tecrübe edilmesine neden olmaktadır (Standing, 2014, ss. 40-48).

Sürekli yoksunluk ile savaş hâlinde olan prekarya, kendisi için sınıf olma özelliğini tamamlayamamıştır. Dahası istikrarsız emek, düşük ve öngörülemeyen gelirler ve vatandaşlık haklarının kaybı ile gittikçe daha tehlikeli hâle gelmektedir. Prekarya için "yeni tehlikeli sınıf” tanımlaması yapan Standing, (2012, 2014, 2018) kronik güvencesizlik hâlinin prekaryayı kendine ve etrafına zarar vermeye yöneltebileceğini belirtmektedir. Bu durum ise prekaryayı sağcı popülizmin kucağına b1rakmaktadır. Hâkim kurumlar ve iktidar yapılarında iyileşme isteyen bir "emekçilik 
politikasına" geri dönmek yerine yeni bir "cennet siyasetinin” kök-dal değişimini aramaktadırlar (Standing, 2018, s. 1). Bu arayışta ise prekarya, tehlikeli sınıf olma durumunu pekiştirmektedir. Tüm bunlara rağmen Standing, prekaryaya toplumu dönüştürücü bir görev vermemektedir. Aslında bu bir uyarı mahiyetindedir. Prekaryanın yoksunluğu ve öfkesi gerekli düzenlemeler yapılmazsa kaosa ve istikrarsızlığa neden olabilecektir.

\section{Standing'in Tezleri Etrafındaki Tartışmalar ve Eleştiriler}

Standing'in prekaryayı yeni bir sınıf ve birleştirici bir unsur olarak tahlil etmesi, tartışmalara önemli bir katkı yapmıştır. Esnek istihdam ve güvencesizlik temelinde şekillenen üretim sisteminde prekaryayı daha nesnel olarak kabul edip onu sürecin dezavantajlı konumunda bulunanların bir araya getirici gücü olarak görmektedir. Kadınlar, göçmenler, engelliler, gençler ve daha birçok farklı gruptan geçişin olduğu bu grup sürekli oluşum hâlindedir. Standing ve sonrasındaki tartışmalar ise bu gücün gün geçtikçe politize olduğunu iddia etmektedir.

Prekarya bir aktör müdür yoksa grup mu? Sosyoekonomik bir durumu mu temsil etmektedir yoksa toplumsal bir sınıfı mı? Prekaryayı toplumsal realitenin bir parçası olarak temel alan Standing, tanımlama yaparken kavramsal bir çerçeve çizememektedir. Sınıf olarak tanımlamasının yanı sıra çalışmaları içerisinde sosyoekonomik bir grup (2014, s. 21) ve güvencesizlik üzerinden bir durum olarak da tanımlanmaktadır. Marksist literatüre dayanarak bir yandan "oluşmakta olan bir sınıf" tanımlaması yaparken diğer taraftan sınıf yapısı içerisinde bir konum vermeye çalışmaktadır (Standing, 2014, s. 7). Ayrıca bahsettiği sınıf sistemi içerisinde hiyerarşi, eşitsizlik, tahakküm gibi referans vererek Marksist terminolojiyi kullanmaktadır. Öte yandan ise Weber'e referansla iş ve mesleklere, gelirin belirleyiciliğiyle oluşan statüye referans vermektedir. Oluşturduğu sınıf şeması içerisinde yer alan konumlar (elitler, profesyoneller, maaşlilar, işsizler vd.) ise neo-Weberyan ekolün çerçevesini oluşturmaya çalıştığı bir düzlemde ilerlemektedir. Kavramın çerçevesinin oluşturulmamış olması, tanımlamadaki muğlaklıklar ve dayandığı literal farklılıklar, Standing tanımladığı prekaryaya yoğun eleştirilerin gelmesine neden olmuştur. Bu kapsamda Standing'e gelen eleştiriler üç başlık altında değerlendirilmektedir:

(i) Yeni bir sınıf olarak tanımlanmasına yöneltilen eleştiriler,

(ii) Avrupa merkezci bakış açısı ve coğrafi yanlılık eleştirileri,

(iii) Güvencesizliğin yapısal bir sorun olması tartışması. 
$\mathrm{Bu}$ anlamda bu eleştirilerin ihmal ettiği dördüncü bir nokta bulunmaktadır. Standing toplumsal sınıfların dinamikliğini ve değişken özelliklere sahip olduğunu ihmal etmektedir. Dolayısıyla eski sınıfsal niteliklerle yeni toplumsal grupları değerlendirmek gibi bir hataya düşmektedir. Aşağıda Standing'e yöneltilen eleştiriler tartışılıp bu dördüncü nokta değerlendirilecektir.

\section{Prekaryanın Yeni Bir Sınıf Olarak Tanımlanması}

Standing'in kitabının popülaritesinin ardından prekarya, 2013'te BBC ve Manchester Üniversitesi tarafından düzenlenen Büyük Britanya Sınıf Araştırması'nda en düşük sınıf olarak seçilmiştir. Savage ve arkadaşları (2013) tarafından hazırlanan araştırma raporunda yeni bir sosyal sınıf modeli oluşturulmuştur. Araştırmacılar, sınıf ve tabakalaşma analizinin üçüncü aşamasına girerek gizli bir sosyal sınıf analizi önermektedir. Bu gizli sınıf analizi, istatistiksel bir modelin bazı parametrelerinin, kategorik bir gizli değişkenin kategorilerini oluşturan gözlemlenmemiş alt gruplar arasında farklılık gösterdiği fikrine dayanmaktadır (Savage vd., 2013, s. 11). Modellerinde araştırmacılar, Bourdieu'nun kültürel, ekonomik ve sosyal sermaye kavramlarını kullanarak Birleşik Krallık toplumu için yedi sınıflı bir model oluşturmuşlardır:

(i) Elitler (elites),

(ii) Yerleşik orta sınıf (established middle class),

(iii) Teknik orta sınıf (technical middle class),

(iv) Yeni müreffeh işçiler (new affluent workers),

(v) Geleneksel işçi sınıf (traditional working class),

(vi) Yükselen hizmet işçileri (emergent service workers),

(vii) Prekarya (precariat).

Bu şemada Savage ve arkadaşları (2013), Standing'i referans aldıklarını belirterek prekaryayı bir sınıf olarak temizlikçi, şoför, bakım işçisi, marangoz ve kasiyer gibi meslek gruplarını kapsayan güvencesiz, ekonomik, kültürel ve sosyal sermayeden yoksun olarak tanımlanmaktadırlar.

Prekaryayı anlama ve konumlandırma çalışmaları sırasında prekaryanın yeni bir sınıf olarak tanımlanıyor olması, Standing referans verilerek daha fazla tartışılmasına neden olmuştur. Bu tartışmalar, prekaryanın kendi için bir sınıf oldu- 
ğundan yeni proletarya olmasına kadar uzanmaktadır. Standing'in prekaryayı bir sınıf olarak tanımlamasını eleştirenlerden biri, ünlü Marksist sosyolog Eric Olin Wright'tır. Wright (2016), işçi sınıfının büyük kısmını oluşturan prekaryanın, kapitalizm karşısındaki hoşnutsuzluğunu ifade etmesinin onun bir sınıf olarak tanımlanamayacağını ancak hak çerçevesinde açıklanabileceğini belirtmektedir. Ayrıca sınıf analizi yapmanın aynı zamanda sosyal bölünmeleri ve dönüşüm olanaklarını teorik olarak anlamanın tutarlı ve anlaşılır bir yolunun geliştirmesine katkı sağlaması gerektiğini belirtmektedir. Bu nedenle kavramların öncelikle paylaşılan ve çatışan çıkarların doğasını aydınlatan kesin anlamları olması önemlidir. Bu amaç doğrultusunda prekaryayı bir sınıf olarak ya da "oluşmakta olan bir sınıf" olarak tanımlamak, onun içeriğini netleştirmekten çok onun daha fazla üstünü örtmek anlamina gelmektedir.

Prekaryanın bir sınıf ya da durum olduğunu tartışan bir diğer isim ise Peter Frase'dir. Standing'in tanımlamaları üzerinden eleştiriler getiren Frase (2013), prekaryanın 21. yüzyılda işçileri bir araya getirecek bir güç potansiyeli taşımadığını, "yeni bir sınıf" olarak tanımlanamayacağını belirtmiştir. Öte yandan prekarya, eskinin emekçisi ve endüstriyel proletaryası da olmayacaktır. İlerleyen zamanlarda prekarya üzerine teorileri üretenlerin bu tanımlamaları yapabilmek ve süreci değerlendirmek için yeni ampirik eğilimleri araştırması, iş ve emek konusunda yeni bulguların ortaya çıkarılmasında rol almaları gerekmektedir.

“Güvencesizlik, ayrı ve farklı bir sınıflaşma meydana getirir mi?” sorusu üzerinden ilerleyen Palmer (2014) ise sayısız ve sonsuz ihtimal yelpazesi bulunan bu durumun farklı özgül ve tikel sınıf yapıları oluşturacağını belirtmektedir. Güvencesizlik ve proleterleşmeyi aynı düzlemde değerlendirmenin hem mücadele hem de pratik açısından bölücü ve zararlı sonuçları bulunmaktadır ve meselenin üzeri örtülmektedir (Palmer, 2014, s. 42). Hâlbuki tüm proleterler güvencesizlikten rahatsızdırlar ve güvencesizlikle sınırlananlar aslında proleter ya da mülksüzler sınıfıyla direkt örtüşen çıkarlara sahiptirler (Palmer, 2014, s. 57).

Prekaryanın yeni proletarya olup olmadığı veya sadece aşağı doğru hareket eden orta sınıfların çocukları olup olmadığı konusunda tartışmalar bulunmaktadır. Foti'ye (2017) göre bunların her ikisidir de. Güvencesizlik, bir neslin sınıf hâline gelmesine neden olmaktadır. Hem tarihsel bir aktör hem de ilerlemeci kolektif olarak hareket eden bir gruptur. Marx'ın terminolojisi ile ifade etmek gerekirse hem emek sahibi hem de bu emeğin farkındalığına sahiptir. Aynı zamanda da bu çalışan güvencesiz insanlar, sömürünün muhatabı olan bir toplumdur. Güvencesiz aktör- 
lerin kimlikleri temelde milliyetçi veya kültürel normlardan ziyade sosyal statüden dışlanmaya dayanır. Bu sınıf; genç, geçici şehirli, hem orta sınıf hem de proletarya temelli ve kuzey ülkelerinde yaşayan ve çalışanlardır (Foti, 2017, s. 44). ${ }^{2}$ Foti'ye (2017, ss. 39-40) göre 21. yüzyılın kapitalist birikim biçimi içerisindeki hizmet sektörünün güvencesizleri 20. yüzyılın kapitalist servetinin oluşmasında etkin rolü olan proletarya ile eş değerdir. Foti'nin yorumuna benzer bir şekilde Bora ve Erdoğan da (2013, s. 30) prekaryanın bu zamanın proletaryası olduğunu belirtmektedir. Tıpkı kapitalizmin ortaya çıkışındaki gibi güvencesiz koşullarda, "lüzumsuz" ve "tehlikeli” olarak görülebilecek statüsüz bir kitledir.

Avrupa'daki toplumsal muhalefet gösterileri ile güvencesizliğin "ofansif” bir stratejinin tetikleyici anahtar sözcüğü olarak prekaryayı tanımlayan Oğuz (2011) ise kavramı, sınıf perspektifinden ele almaktadır. TEKEL Direnişi ile birlikte konuyu değerlendiren Oğuz (2011, s. 20), farklı emek kesimlerini bir araya getirerek sınıf mücadelesi içerisinde özgün bir önemi bulunan prekarya kavramının yeni bir sınıf tanımlaması olarak görülemeyeceğini belirtmektedir. "Proletaryaya karşı prekaryayı" konumlandırmak, farklı emek kesimleri arasındaki farklılıkları mutlaklaştırmak ve sınıfın belirleyiciliğini etkisizleştirmektir.

"Küresel sınıf” tartışmasına eleştiri getiren bir diğer isim ise Jan Breman'dır. Breman'a (2013) göre Standing'in prekarya olarak tanımladığı geçici ve yarı zaman$l_{1}$ iş̧̧ilerin emeğini satmaktan başka hayatta kalma imkânı olmayan klasik proletaryadan bir farkı yoktur. Ayrıca Standing "küresel sınıf” tanımlaması yaparken aslında gelişmiş kapitalist devletler üzerinden karşılaştırma yapmakta ve dünyadaki iş gücünün durumunu hesaba katmamaktadır (Breman, 2013, s. 136).

2 Prekarya çok farklı beceri ve eğitim seviyelerine sahip iki işçi kategorisinden oluşur: Kısıtlı ancak standardize edilmiş iş normları altında perakende ve düşük kaliteli hizmetlerde çalışan pembe yakalılar (kasiyer, temizlikçi, kapıc1, aşçı, garson vb.) ve dünyanın önde gelen şehirlerini birbirine bağlayan, bilgi ekonomisinde, bazen yüksek ücret oranlarına ulaşabilen dijital yaratıcı sınıf (editörler, grafik sanatçılar, programcılar vb.). Dahası prekarya, farklı cinsiyetteki gençlerin çoğunluğu oluşturduğu farklı sınıflar ve farklı etnik kökenlerden oluşmaktadır (Foti, 2017, s. 39). Bu temel ikili kategorileştirmeden sonra Foti (2017, s. 24) prekaryayı kendi içinde dört sınıf olarak ele almaktadır: (i) Yaratıcı sınıf (artistler, kodlayıcılar, mühendisler, tasarımcılar), (ii) yeni işçi sınıfı (depolama, lojistik, endüstriyel üretim, gıda işleme, inşaat alanlarında vasıfsız işçi veya teknisyen olarak, taşeron istihdam), (iii) hizmet sınıfı (garsonlar, kasiyer, temizlikçi, fast-food çalışanı veya eğitimci olarak çalışanlar), (iv) işsiz sınıf (kısa ve uzun süreli işsizler, iş gücü kesintileri, iş gücü refah alıcıları, yasadışı göçmenler ve mülteciler). 


\section{Avrupa Merkezci Bakış Açısı ve Coğrafi Yanlılık Eleştirileri}

Standing'e gelen eleştirilerden bir diğeri ise kavramın Avrupa merkezci bir bakış açısıyla ele alınması ve coğrafi yanlılığı ile ilgilidir. Munck (2013) ve Scully (2016), Standing'in kavramını kullanırken güvencesizleşmenin küreselleşmenin bir ürünü olarak dünyadaki tek fenomen olarak açıklamasını eleştirerek onun Avrupa merkezci bir yaklaşıma sahip olduğunu iddia etmektedirler. Munck (2013), prekaryanın "Kuzey"den referanslarla açıklamasına itiraz edilerek iş gücünün açıkça daha "güvencesiz" göründüğü “Güney”in deneyiminin aktarılmasında yetersiz kalındığ1nı belirtmektedir. Hatta Munck (2013), Standing'in aklındaki ekonomik ve politik kalkınma modelinin gerçekte sadece İngiltere olduğunu ve dünyanın Kuzey Atlantik dışındaki herhangi bir bölgesine atıfta bulunulmadığını belirtmektedir. Güvencesizlikten bahsedilecekse bunun merkezi, refah devleti sistemini hiçbir şekilde deneyimlememiş olan Güney olmalıdır (Munck, 2013, s. 752). Nitekim Standing (2014), tartışmalara zemin teşkil eden Prekarya: Yeni Tehlikeli Sinıf kitabında küreselleşme ile birlikte yaşanan güvencesizlik ve çok uluslu şirketlerin diğer coğrafyalardaki etkilerini Kıta Avrupa'sını esas alarak değerlendirmektedir. Avrupa dışında ise Amerika, Japonya, Çin ve Hindistan üzerinden örnekler vererek değerlendirme yapmaktadır.

Scully (2016) ise küreselleşmenin sonucu olarak lanse edilen prekaryanın aslında çok daha uzun bir hikâyesinin olduğunu ve Güney ülkelerindeki emek süreci incelenmeden bu değerlendirmelerin yapılamayacağını belirtmektedir. Güney ülkeleri uzun süre kolonileştirilmişlerdir ve güvencesizlik aslında bu ülkeler için sabit bir çalışma rutinidir. Dahası Güney'deki sınıf yapısını güvence altında olanlar ve güvencesiz çalışanlar şeklinde ayırmak oldukça zordur. Ülkeler arasındaki bir diğer farklılık ise Standing tarafından prekarya için belirleyici unsur olan vatandaş olmamak ya da sağladığı haklardan mahrum olmak, Güney ülkeleri için geçerli değildir. Uzun süre sömürge altında yaşayan halk, büyük ölçüde vatandaşlık haklarından çok daha önce mahrum bırakılmışlardır. Bağımsızlıklarını ilan etmelerine rağmen işçi haklarına tam anlamıyla erişimleri mümkün olmamıştır. Scully’e (2016, ss. 166-168) göre ülkeler arasındaki bu değişkenliklerin açık bir şekilde değerlendirilmesi, meselenin çok yönlü anlaşılmasına imkân sağlayacaktır.

Güvencesizliğin ve prekaryanın analiz edilebilmesi için farkı coğrafyalardaki görünümlerinin önemli olduğunu belirten bir diğer çalışmada ise Melin ve Blom (2015), İngiliz bir ekonomist olan Standing'in Anglosakson toplum içinde çalışma hayatındaki güvencesizlik üzerinden bir analiz geliştirdiğini belirtmektedir. Avrupa'nın geneline bakarsak sınıf rejimlerindeki üretim rejimleri ve refah rejimleri 
arasındaki farklar çok önemli olabilir. Fakat prekaryadan bahsetmek ve anlaşılabilmesini sağlamak için birbirine çok benzemeyen ülkeler hakkında karşılaştırmalı bir bakış açısı benimsenmelidir. Nitekim araştırmasında Rusya ve İskandinav ülkelerinde bu bağlamda karşılaştırma yapan Melin ve Blom (2015), sınıf rejimi açısından da açıkça farklılık gösteren iki bölgede prekaryanın aynı sınıflandırmaya konulamayacağı sonucuna ulaşmıştır. Güvencesizliğin konumu ve rolünün ve hatta kavramın içeriğinin birbirinden ayrılması gerektiğini belirtmektedirler.

\section{Güvencesizliğin Yapısal Bir Sorun Olması Tartışması}

Prekaryanın tanımlanmasından bir sosyal hareket olarak çözümlenmesine kadar analiz eden çalışmalar temelde prekaryanın yapısal olarak bir sorun olduğuna vurgu yapmaktadır. Burada en temel iddia, güvencesizliğin kapitalizmin doğasında bulunduğu ve bu bağlamda neoliberalizmin şekillendirdiği yeni üretim biçimindeki esneklik ve güvencesizliğin istisnai bir durum olmadığıdır. İkinci Dünya Savaşı sonrasında refah devleti politikaları ve işçilere tanınan haklar ile bir süre görünmez hale gelmiş, üstü örtülmüştür (Neilson ve Rossiter, 2008; Gambino, 1996; Frase, 2013; Munck, 2013).

Neilson ve Rossiter'e (2008, s. 54) göre güvencesizlik yalnızca Fordist veya Keynesyen uygulamalarla birlikte değerlendirildiğinde düzensiz bir fenomendir. Kapitalizme daha geniş bir tarihsel ve coğrafi açıdan bakıldığında güvencesizlik sadece Fordist ekonomik örgütlenme içerisinde eğreti duran bir normdur. Diğer açıdan bakıldığında ise düzenli ve istikrarlı çalışma, sömürgecilik sonrası dünyada hiçbir şekilde ilke olarak görülmemiştir (Munck, 2013, s. 752). Nitekim güvencesizliği politik bir kavram olarak anlamak için tüm Fordist üretim, çalışma organizasyonu modları, refah desteği, teknolojik inovasyon ve politik mücadele tekrar gözden geçirildiğinde neoliberalizmin istisnai olduğunu söylemek oldukça güçtür. Neilson ve Rossiter (2008), Fordizmi istisna olarak konumlandırırken kapitalizmi ve dahi Fordizmi homojen olarak kabul etmemektedir. Her ikisi de ulusal, jeokültürel ve tarihî bağlamların yanı sıra kurumsal uygulamaların şekillendirdiği içsel değişkenliklere, dışsal eğilimlere ve karşılıklı tutarsızlıklara sahiptir. Dahası hem ontolojik deneyim hem de işçilik koşulu olarak güvencesizliğin çokluğu buna çok yakından bağlıdır. Sonuç olarak Neilson ve Rossiter (2008), güvencesizlik söyleminin küresel ölçekte çağdaş emeğin tanımlayıcısı olarak tercüme edilemeyeceğini açık bir biçimde ifade etmektedir. Prekarya esasen Fordizmin ve Kuzey'de de sosyal devletin çöküşüyle bağlantılı bir analitik ve politik kavramdır. 
Güvencesizliğin bir koşul olduğunu iddia edenlere karşın Standing, bunun bir koşul olduğunu fakat bir koşulun hareket imkânı olduğunu ama insan unsurunun olmadığını belirtmektedir. Hâlbuki prekarya oluşmakta olan bir sınıftır. Onun hazırlık aşamasında olduğu belirtilebilir. Nitekim küresel dönüşümden bahsedilecekse prekarya onun en alt ve ana dalgasını oluşturmaktadır (Standing, 2015, ss. 5-6).

\section{Prekaryayı Sınıfların Konum Kaybı Olarak Tartışmak}

Standing ile başlayan prekaryanın bir sınıf olma durumu özellikle Marksist çevreler tarafından sert bir biçimde eleştirilmiştir. Prekaryanın bir sınıf mı yoksa bir durum mu olduğu tartışmaları, esnek istihdam, güvencesizlik, enformalleşme gibi yapısal değişimlerle birlikte okunduğunda daha farklı bir tartışma boyutu kazanmaktadır. İş gücündeki değişen dengeler, teknolojinin aktif kullanımı, üretim sisteminin değişmesi ile yeni imkânların ortaya çıkışı, çalışan kesimi ister mavi yakalı ister beyaz yakalı olsun farklı yönleriyle etkilemektedir. Üretim yapılarından çalışma ilişkilerine, istihdama kadar birçok yönü olan güvencesizlik aslında yeni oluşan bir durum değildir. Literatürdeki birçok tartışma (Gambino, 1996; Neilson ve Rossiter, 2008; Frase, 2013; Munck, 2013) kapitalizmin esas doğasının bu güvencesizlik üzerine oturduğu ve "altın yıllar" olarak belirtilen refah devleti politikalarının etkin olduğu 1945-1970 arasındaki dönemin “istisna” olduğu kabulü üzerinden ilerlemektedir. Tarihsel ve coğrafi olarak yakından incelendiğinde güvencesizliğin kapitalizm için bir norm olduğu görülecektir. Öte yandan ise Kuzey ülkelerinde yeni bir vaka olarak resmedilen güvencesizliğin dünyanın üretim merkezinin Güney ülkelere kayd1ğ1 dönemde de yaşandığı bilinmektedir. Bu durum ise prekaryanın "yeni bir sınıf" ya da "yeni bir durum" hâli olarak tanımlamanın yetersiz olduğunu göstermektedir.

Toplumsal hareketliliği eğitimle, meslekle dahası çok çalışarak sürekli ve aktif hâle getirmeyi vadeden modernite ve onun ekonomik bir formu olarak kapitalizme olan inancın sarsılması da bu sürecin bir diğer yüzünü oluşturmaktadır. Emeğin esnekleşmesi, çalışma koşullarının belirsizliği, vasfa uygun iş bulabilme ve istihdam garantisinin olmaması gibi durumlar, çalışan kesimi daha da belirsiz ve güvencesiz bir duruma çekmektedir. Nitekim sistemin işleyişinin temel grubunu oluşturan orta sınıf, sınıfların parçalanması ile kapsamlı dönüşümler geçirmektedir. "Sistemin sadık ve itaatkâr hizmetkârları" (Vatansever, 2018) olan orta sınıfın ya da bir başka ifade ile beyaz yakalıların emeklerinin vasıfsızlaşması (Bora ve Erdoğan, 2013), gelirlerinin azalması, sınıf kaybı yaşama durumları, literatürdeki bazı çalışmalarda prekaryanın yeni bir özne olarak ortaya çıkması olarak yorumlanmaktadır. Hâlbuki bu durum da neoliberal devlet politikaları ile piyasa merkezli yaklaşım ve düzenlemelerin, üretimin esnekleşmesinin ve güvencesiz hâle gelmesinin yalın bir 
tezahürüdür. Emeğin sermaye karşısındaki gücü gittikçe zayıflamakta, prekaryalaşmaktadır. Bu durumda ise prekarya, kapitalizme "içkin" olan bir durumun farklı bir "formu" olarak karşımızda durmaktadır.

Meseleye sınıflar üzerinden değil "ücretli toplum” analizi üzerinden yaklaşan Castel (2017), modern kapitalist sistemin işleyişinden, beraberinde getirdiği teknolojik-ekonomik gerekliliklerden kaynaklı toplumsal ölçekte giderek fazlalaşan bir katmanlaşma durumu olduğunu belirtmektedir. Toplumsal farklılaşma da geri dönüşü olmayan şekilde karmaşıklaşan sistemde ücretli emek toplumda yapısal bir konum elde etmektedir (Castel, 2017, s. 289). Emeğin dönüşümü ile şekillenen bu süreçte esneklik ve güvencesizlikle birlikte çerçevesi çizilen yeni çalışma biçimi, emeğin prekaryalaşması ${ }^{3}$ ile karşı karşıya kalmıştır. Bu durumu “yeni sosyal sorun” olarak tanımlayan Castel (2017), günümüzdeki sorunun ise sadece "eğreti bir çeperin" oluşması değil "istikrarlı olanın da istikrarsızlaşması" olarak değerlendirmektedir. Prekaryalaşma sürecinin istihdam konusunda istikrar sağlanan yerlerde başlaması, kitlesel olarak korunmasızlığın artmasını beraberinde getirmektedir (Castel, 2017, ss. 371-372). Ücretli emeğin çalışan kitlesini oluşturan hizmet sektörü çalışanları, "eğreti çeperin" içerisinde "istikrarsızlığın" farklı yönlerini deneyimlemektedirler. Emeğin esnekleşmesi, çalışma koşullarının belirsizliği, vasfa uygun iş bulabilme ve istihdam garantisinin olmaması gibi durumlar, çalışan kesimi daha da belirsiz ve güvencesiz bir duruma çekmektedir. Sadece esnek ve güvencesiz çalışma koşulları ile açıklanamayacak "eğretilik" aslında ücretli çalışanların sosyoekonomik konumlarında da söz konusudur. Modern toplumun liyakat basamaklarını Sennett'in (2017) tabiriyle eğitim yoluyla elde ettiği "yetenek rozetleri” ile kararlılıkla çıkan birey için her yeni günde yeni ve farklı talepler ortaya çıkmaktadır. Çalışma biçimleri, enformasyon, tüketim ve toplumsal hayatın bileşeni konumunda bulunan birçok detay değiştikçe insanlar yeni stratejiler üretmektedir. Ne var ki değişimin hılılığı ve sosyal-iktisadi sistemin işleyişi, emeğin sürekli eğretileştiği bir düzende bireyi çaresiz bırakmaktadır.

Bu noktada kapitalizme içkin olan güvencesizlik içerisinde prekarya, "yeni bir sınıf", “yeni bir durum" ya da "sınıf ötesi bir özneleşmenin" ifadesi olarak tanımlanmaktan ziyade toplumsal sınıfların dinamikliği ve sürekliliği içerisinde ele alınmalıdır. Son dönemde yoğunlaşan toplumsal hareketleri de içine alarak toplumsal grupların içerisinde bulunduğu durum yeniden değerlendirilmelidir.

3 Castel'e (2017, s. 365) göre ise emeğin prekaryalaşmasına vurgu yapmak sosyal korunmasılığı besleyen ve yolun sonunda ise işsizliğe ve mensubiyet yitimine yol açan süreci anlaşılmasını ve tanımlanmasını sağlar. 


\section{Sonuç}

1980'lerde başlayan ve küreselleşme ile hızlı bir biçimde yayılan ekonomik güvensizlik ve istihdamdaki güvencesizlik, çağdaş kapitalizm tartışmaları içerisinde önemli bir yer tutmaktadır. Bu eğilimlerin yeniden kavramsallaştırılması ise prekaryanın bir durum/koşul olma durumundan bir sınıf olma durumuna kadar oldukça tartışmalıdır.

O hâlde prekaryayı nasıl tanımlamak gerekmektedir? Öncelikle yeni tehlikeli stnif olarak "haklı" ve "mağdur" olarak tanımlanan prekarya, sınıf ve güvencesizlik ilişkisindeki dar bağlamdan çıkarılmalıdır. Zira bu ilişki bağlamında değerlendirildiğinde fabrikada çalışan bir iş̧̧i, emeğini sermayedara ücret karşllığında sattığında aslında yapısal olarak güvencesiz kalmaktadır. Öte yandan hem coğrafi hem de tarihsel olarak bakıldığında güvencesizlik hâlinin İkinci Dünya Savaşı sonrasındaki kısa dönemli süreç haricinde günümüzdeki güvencesizliğin önceki dönemlerden farklı olmadığı görülmektedir. Bu nedenle prekarya, kapitalizmde yapısal olarak içkin bulunan güvencesizliğin farklı bir formu olarak görülmelidir. Standing tarafından yüksek sesle dile getirilmeye başlanan prekarya ve ona eleştiri olarak getiren birçok tartışmada yeni bir sınıf olarak görme ya da proletaryanın bir parçası olarak yorumlama eğilimi tartışılmaktadır. Fakat Standing'in eski sınıfsal formlar kullanılarak yeniden tanımlama çabası eleştirilmemiş hatta aynı zeminde farklı gerekçelerle tartışılmıştır. Hâlbuki emeğin ücretlileşmesinin gittikçe belirginleştiği günümüzde, toplumsal grupların değişen konumları ampirik araştırmalarla desteklenerek yeniden değerlendirilmeye muhtaçtır.

\section{Kaynakça | References}

Bauman, Z. (2000). Liquid modernity. UK: Polity Press.

Beck, U. (1992). Risk society: Towards a new modernity. London: Sage Publications.

Bora, T. ve Erdoğan, N. (2013). 'Cüppenin, kılıcın, ve kalemin mahcup yoksulları': Yeni kapitalizm, yeni işsizlik ve beyaz yakalılar. A. Bora, T. Bora, N. Erdoğan ve İ. Üstün (Ed.). Boşuna mı okuduk? Türkiye’de beyaz yakahı işsizliği içinde. İstanbul: İletişim.

Breman, J. C. (2013). A bogus concept? New Left Review, 84, 130-138.

Butler, J. (2006). Precarious life: The power of mourning and violence. London: Verso.

Foti, A. (2017). General theory of the precariat: Great recession, revolution, reaction. Amsterdam: Institute of Network Cultures.

Frase, P. (2013). The precariat: A class or condition? New Labor Forum, 22(2), 1-14.

Gambino, F. (1996). A critique of the Fordism of the regulation school. http: www.wildcat-www.de/en/zirkular/28/ z28e_gam.htm adresinden 20.07.2019 tarihinde erişilmiştir. 


\section{insan \& toplum}

Giddens, A. (1991). Modernity and self-identity. New York: Polity Press.

Kalleberg, A. L. ve Vallas, S. P. (2018). Probing precarious work: Theory, research, and politics. A. L. Kalleberg ve S. P. Vallas (Ed.). Precarious work (Research in the sociology of work, 31) içinde (ss. 1-30).

Lazzarato, M. (1996). Immaterial labour. P. Virno ve M. Hardt (Der.). Radical thought in Italy: A potential politics (theory out of bounds) içinde (ss. 133-150). University of Minnesota Press.

Lorey, I. (2011). Governmental precarization. http://eipcp.net/transversal/0811/lorey/en adresinden erişilmiştir.

Lorey, I. (2016). State of insecurity: Government of the precarious. London: Verso.

Melin, H., Blom, R. (2015). Precarity in different worlds of social classes. D. Porta, S. Hänninen, M. Siisiäinen ve T. Silvasti (Ed.). The new social division: Making and unmaking precariousness içinde. UK: Palgrave.

Munck, R. (2013). The precariat: A view from the south. Third World Quarterly, 34(5), 747-762.

Neilson, B. ve Rossiter, N. (2008). Precarity as a political concept, or, Fordism as exception. Theory Culture Society, 25(7-8), 51-72.

Oğuz, Ş. (2011). Tekel direnişinin ışığında güvencesiz çalışma/yaşama: Proletaryadan "prekarya”ya mı? Mülkiye Dergisi, 35(271), 7-24.

Palmer, B. (2014). Reconsiderations of class: Precariousness as proletarianization. Socialist Register, 50, 40-62.

Savage, M. vd. (2013). A new model of social class: Findings from the BBC's Great British class survey experiment. Sociology, 47(2), 219-250.

Scully, B. (2016). Precarity north and south: A southern critique of Guy Standing. Global Labour Journal, 7(2), 160172.

Sennett, R. ve Cobb, J. (2017). Sinıfın gizli yaraları. İstanbul: Heretik Yayıncılık.

Standing, G. (2012). The precariat: From denizens to citizens? Polity, 44(4), 588-608.

Standing, G. (2014). Prekarya: Yeni tehlikeli sınıf. İstanbul: İletişim Yay.

Standing, G. (2015). The precariat and class struggle. RCCS Annual Review, 7, 3-16.

Standing, G. (2018). The-precariat-todays's transformative class?, Great Transition Initiative, https://www.greattransition.org/publication/precariat-transformative-class.

Sunar, L. (2018). Sosyal tabakalaşma: Kavramlar, kuramlar ve temel meseleler. Ankara: Nobel Akademik Yayıncılık.

Vatansever, A. (2018). Proleterya ile orta sınıf arasında: Siyasi aktör olarak prekarya. L. Sunar (Ed.). Türkiye'de toplumsal tabakalaşma ve eşitsizlik içinde (ss. 181-218). Ankara: Nobel Akademik Yayıncılık.

Wright, E. O. (2016). Is the precariat a class? Global Labour Journal, 7(2), 123-135. 